\title{
PENGGUNAAN MEDIA SOSIAL PATH SEBAGAI SARANA PENGAKUAN SOSIAL
}

\author{
Ardi Maulana Nugraha ${ }^{1}$, Karim Suryadi ${ }^{2}$, Syaifullah Syam ${ }^{3}$ \\ 1SMA Al Burhan \\ 2Dosen Program Studi Pendidikan Sosiologi \\ ${ }^{3}$ Dosen Program Studi Pendidikan Sosiologi
}

\begin{abstract}
ABSTRAK
Fenomena penggunaan media sosial di kalangan remaja semakin memprihatinkan, dimana remaja menggunakan media sosial path sebagai sarana eksistensi diri, ruang untuk menyalurkan apa yang mereka rasakan, dan memposting semua aktifitas yang dilakukan. Tujuan penelitian ini untuk mendapatkan gambaran mengenai penggunaan media sosial path sebagai sarana pengakuan sosial di kalangan siswa-siswi. Metode yang digunakan adalah metode studi kasus. Hasil dari penelitian menunjukan bahwa: pertama, pandangan siswa terhadap media sosial path cenderung bersifat positif. Kedua, terdapat tiga penyebab siswa menggunakan media sosial path, yaitu pengaruh yang berasal dari teman-temannya, lalu path sebagai salah satu indikator gaul atau tidaknya individu serta path yang digunakan sebagai sarana aktualisasi diri. Ketiga, tujuan utama siswa menggunakan path adalah untuk mendapatkan pengakuan sosial. Keempat, untuk mendapatkan pengakuan sosial, siswa menganggap harus menampilkan hal yang bersifat positif dan sebaik mungkin.
\end{abstract}

Kata kunci : Media Sosial Path, Pengakuan Sosial, Siswa.

\section{PENDAHULUAN}

Media sosial saat ini menjadi seperti kebutuhan seharihari di kalangan masyarakat khususnya di kalangan remaja. Perubahan penggunaan media sosial tersebut tidak hanya terjadi begitu saja, melainkan melalui sebuah proses.

Menurut Erikson (dalam Mar'at 2009 : 201) mengemukakan bahwa "Seseorang yang sedang mencari identitas akan berusaha "menjadi seseorang", yang berarti berusaha mengalami diri sendiri sebagai "AKU" yang bersifat sentral, mandiri, unik, yang mempunyai suatu kesadaran akan kesatuan batinnya, sekaligus juga berarti menjadi "seseorang" yang diterima dan diakui oleh orang banyak".

Berdasarkan

pada kekhawatiran mengenai perubahan remaja dalam penggunaan media sosial yang cenderung ke arah 
yang negatif, lalu sikap dari masyarakat yang seakan acuh tak acuh pada masalah ini serta dampak fatal yang mungkin bisa timbul dari permasalahan ini.

\section{REMAJA, MEDIA, DAN PENCITRAAN DIRI}

Berdasarkan hasil observasi

dan wawancara yang telah dilakukan, diketahui bahwa hampir semua informan mengatakan bahwa mulai mengenal dan menggunakan media sosial semenjak dari Sekolah Dasar (SD). Usia dimana mereka justru masih sangat membutuhkan pengawasan dan pengasuhan orang tua. Ciri khas pada fenomena penggunaan media sosial di kalangan remaja di SMA Negeri 6 ini yakni semua informan menggunakannya hanya ketika pada waktu tertentu saja.

Para informan siswa mengungkapkan bahwa mereka menggunakan media sosial path, karena pada awalnya media sosial path hanya bisa diakses oleh gadget canggih dan bisa terbilang mahal. Tujuan utama para siswasiswi menggunakan media sosial path adalah untuk mendapatkan pengakuan akan eksistensi diri mereka di hadapan para pengguna path lainnya. Selain itu, media sosial path juga dijadikan sebagai sarana ekpresi diri akan kekesalan, kekecewaan, ataupun kebahagiaan bagi para informan.

\section{KETIDAKTAHUAN ORANG TUA AKAN PERKEMBANGAN TEKNOLOGI}

Rata-rata orang tua siswa mengungkapkan bahwa sebagai orang tua dari mereka tidak mengetahui bahwa putra-putri mereka menggunakan media sosial path, dan juga mereka mengakui tidak begitu paham dengan perkembangan teknologi media sosial saat ini. Dari wawancara yang telah dilakukan, terdapat pula orang tua yang selalu berupaya untuk mengikuti perkembangan teknologi dengan menggunakan media sosial facebook dan BBM agar selalu dapat mengawasi aktivitas anaknya. Para orang tua sendiri dalam menaggapi pengakuan sosial yang sedang marak dilakukan oleh remaja di dalam media sosial sangatlah tidak setuju karena apapun alasannya.

\section{BATAS ANTARA MEDIA, PENCITRAAN, DAN PENGAKUAN SOSIAL}

Pandangan para guru khususnya guru sosiologi mengenai adanya perkembangan media sosial saat ini, terdapat segi positif karena memasuki modernisasi dan globalisasi memudahkan komunikasi dan informasi yang aktual akan mudah didapat. Ini juga bagaimana siswa sendiri dalam tujuan 
penggunaannya. Sebenarnya terdapat berbagai hal yang cukup positif yang bisa didapat dari media sosial path ini. Salah satunya adalah dengan adanya media sosial path, sebagai orangtua siswa di sekolah bisa mengetahui akan adanya aktifitas-aktifitas yang dilakukan oleh siswa. Tetapi orangtua juga harus membekali anak-anak yang sedang tumbuh menuju remaja untuk mendampingi dimana anak menggunakan media seperti media sosial path saat ini terbentuk kepribadian yang lebih baik.

Sebenarnya pengakuan sosial yang diinginkan remaja disini disebabkan dari berbagai faktor. Bisa karena kekurangan akan perhatian dari orangtuanya, sehingga anak mencoba untuk mencari perhatian tersebut di media sosial, lalu karena kurang diperhatikan oleh lingkungan sekitarnya sehingga anak menjadi cenderung introvert dan tidak mau menjadi bersosialisasi dengan teman-temannya. Dan pemanfaatan media sosial sebagai sarana pengakuan sosial tidak apa-apa asalkan cara yang digunakan sesuai dengan nilai dan norma yang berlaku, yang dalam artian tidak memberikan dampak yang negatif terhadap orang lain.

Tetapi yang harus diperhatikan adalah batasan hingga sampai mana pengakuan sosial ini masih dapat diterima. Jangan sampai menjadi berlebihan dan menjadi suatu rutinitas.

\section{PEMBAHASAN}

Hasil penelitian menunjukan bahwa seluruh informan mengetahui akan media sosial path dan menggunakannya dengan interval waktu satu sampai dua tahun. Munculnya media sosial path menjadikan siswa-siswi mengalami perubahan orientasi dalam penggunaan media sosial. Dimana asal muasal media sosial diciptakan adalah untuk menjalin komunikasi dengan seseorang yang tidak bisa ditemui secara langsung. Tetapi media sosial path hadir dengan berbagai fitur yang ditawarkan mendukung agar seseorang mampu menunjukan sebuah hal yang dimana orang lain akan terkagum dengan hal yang diposting oleh seseorang tersebut.

Dari informasi yang didapat peneliti melalui serangkaian proses penelitian, banyaknya siswa-siswi kelas XI yang menggunakan media sosial path, dikarenakan media sosial path merupakan media sosial yang bisa memberitahu aktivititas mereka ke para pengguna lainnya. Berdasarkan hasil wawancara yang dilakukan dengan berbagai informan, ratarata informan merupakan pengguna media sosial path dengan intensitas waktu yang 
cukup tinggi, sehingga mereka lebih cepat dalam menerima informasi mengenai perkembangan media sosial di kalangan remaja saat ini. Sebagaimana pendapat yang dikemukakan oleh Nursiti (2013 : 24) bahwas dampak situs facebook dan twitter mungkin lebih banyak dirasakan oleh kalangan remaja. Karena memang merekalah yang sebagian besar user yang paling aktif. Terutama remaja pada usia sekolah.

Sebagaimana

yang

diketahui secara umum, bahwasanya perubahan sosial tidak akan terlepas dari yang dinamakan dengan dampak, baik itu dampak secara positif maupun dampak secara negatif. Faktorfaktor yang berpengaruh dalam perubahan sosial juga berpengaruh terhadap dampak yang akan terjadi. Sutherland (dalam Nazsir, 2008 : 158) menjelaskan bahwa faktor munculnya perubahan sosial adalah adanya inovasi (penemuan baru), adaptasi (penyesuaian secara sosial dan budaya, adopsi (penggunaan penemuan baru/teknologi). Disini, munculnya media sosial path karena adanya penemuan baru dari aplikasi media sosial itu sendiri, lalu mengadopsi dari media sosial sebelumnya, yaitu facebook dan twitter. Selain itu, perubahan yang terjadi pun juga bisa disebabkan akan ketidakpuasan budaya sebelumnya yang menyebabkan merubah aspek-aspek kehidupan yang ada pada masyarakat. Sebagai sebuah perubahan dalam penggunaan media sosial di kalangan remaja saat ini, media sosial path merupakan salah satu bagian dari salah satu kecanggihan teknologi informasi yang dapat memberikan dampak perubahan sosial di dalam masyarakat saat ini.

Tetapi dampak dari kemunculan media sosial path yang saat ini berkembang di kalangan remaja, cenderung mengarah ke arah dampak negatif. Para informan merasa sudah menggunakan media sosial secara berlebihan, dan juga menjadi seperti ketergantungan terhadap media sosial path. Nursiti (2013:25) mengemukakan bahwa media elektronik seperti komputer, notebook, atau handphone juga menghancurkan secara perlahanlahan kemampuan anak-anak dan kalangan dewasa muda untuk mempelajari untuk mempelajari kemampuan sosial dan membaca bahasa tubuh. Maksudnya adalah seseorang akan mengalami pengurangan interaksi dengan sesama mereka dalam jumlah menit per harinya yang menyebabkan seseorang menjadi anti sosial.

Alasan para siswa menggunakan media sosial path, selain sebagai 
sarana komunikasi, juga untuk menerima informasi terbaru. Sehingga melalui akses media sosial path siswa-siswi kelas XI SMA negeri 6 Bandung menjadi selalu up to date terhadap informasi yang sedang berkembang. Selain itu, dapat diketahui pula bahwa siswa-siswi sudah menjadikan media sosial path sebagai sarana rekreasi mereka, tidak hanya itu, mereka pun menilai bahwa media sosial path sebagai penunjukan simbol gaul dan kerennya suatu individu. Sejalan dengan pendapat Ibrahim (2011 : 68) menyatakan bahwa perubahan pola rekreasi masyarakat sejalan dengan perubahan budaya media, dari budaya lisan, langsung meloncat ke budaya media elektronik dengan sendirinya membawa implikasi yang luas dalam kehidupan masyarakat. Penggunaan media sosial path saat ini merupakan suatu keharusan secara tidak langsung yang tidak dapat terlepas di kalangan remaja. Para informan mengakui bahwaanya mereka menggunakannya dengan ikutikutan teman-temannya. Tetapi yang menarik adalah ketika mereka menggunakan media sosial secara umum hanya pada waktu tertentu saja. Yang dalam artian musim-musiman saja. Berkembangnya media soisial path di kalangan remaja memberikan pengaruh kepada bentuk komunikasi yang dilakukan baik secara individu maupun kelompok.

Secara umum tujuan utama para informan menggunakan media sosial path untuk mendapatkan pengakuan sosial yang berasal dari temantemannya. Di dalam proses pencarian identitas diri, mereka membutuhkan adanya suatu pengakuan dan penghargaan atas apa yang dicapai dari lingkungan sekitarnya. Tetapi terkadang apa yang mereka harapkan tidak sesuai dengan kenyataan yang ada, yang pada akhirnya mereka mencoba mencari dan membuat ruang akan pengakuan sosial tersebut di dalam sebuah media sosial path.

Selain daripada media sosial path membawa dampak secara psofitif dan negatif, media sosial path pula menjadi salah satu alat ukur harga diri seseorang khususnya remaja. Ini membuat path menjadi media yang di manfaatkan sebagai sarana pengakuan sosial. Vaughan (dalam Sarlito dkk, 2012 : 57) menjelaskan bahwa setiap orang menginginkan harga diri yang positif. Biasanya motif seseorang dalam menginginkan harga diri positif adalah karena harga diri yang positif membuat orang dapat 
mengatasi kecemasan, kesepian, dan penolakan sosial.

Hal yang menarik adalah ketika terdapat salah satu informan yang sering melakukan pencitraan diri di dalam akun media sosial path nya dengan cara membuat fake moment atau kejadian palsu yang dibuat seolah-olah nyata. Goffman (dalam Ritzer, 2010 : 303) menjelaskan bahwa jarak peran adalah fungsi status sosial seseorang. Orang yang berstatus sosial tinggi lebih sering menunjukan jarak sosial karena alasan yang berbeda dengan orang yang berada pada status sosial rendah. Orang yang berstatus sosial rendah biasanya menunjukan sikap yang lebih bertahan dalam mempertontonkan jarak peran. Dunia maya pun tidak luput menjadi tempat yang dapat digunakan oleh semua orang yang ingin menampilkan kesan diri sebaik-baiknya. Didalam pencitraan diri, berdasarkan hasil observasi dan juga wawancara, peneliti melihat bahwa diri informan bukanlah milik informan itu sendiri, tetapi sebagai hasil dari interaksi antara informan dengan para pengguna media sosial path lainnya, selain itu diri mereka seolah-olah diciptakan karena adanya pengaruh dramatis dari suasana yang ditampilkan. Ini dikarenakan diri merupakan hasil dari pengaruh dan mempengaruhi antara pengguna media sosial path dan pengguna media sosial path lainnya yang dimana maka mudah sekali untuk dipengaruhi dan berubah.

\section{PENUTUP}

Pandangan siswa-siswi terhadap media sosial path cenderung bersifat positif. Hal ini karena bagi mereka media sosial path dianggap sebagai media yang bersifat eksklusif. Terdapat tiga penyebab siswa-siswi menggunakan media sosial path, yaitu pengaruh yang berasal dari teman-temannya, dimana mereka mencoba mengimitasi dan beradaptasi untuk bisa mengikuti trend penggunaan media sosial yang sedang berkembang di kalangan remaja saat ini. Lalu berkembangnya media sosial path sebagai media sosial yang bersifat eksklusif, menjadikan media sosial path dipandang sebagai salah satu indikator gaul atau tidaknya individu.

Secara umum tujuan utama siswa-siswi menggunakan media sosial path adalah untuk mendapatkan pengakuan sosial yang berasal dari temantemannya.

\section{DAFTAR PUSTAKA \\ Buku}

Mar'at. 2011. Psikologi Pendidikan. Jakarta: Penerbit Erlangga. 
Nazsir, R.N. 2008. Sosiologi Kajian Lengkap Konsep dan Teori Sosiologi Sebagai IImu Sosial. Bandung: Widya Padjajaran

Ritzer, G. 2010. Teori Sosiologi Modern. Jakarta: Kencana Media Prenada Group

Sarlito, dkk. (Penyunting). 2012. Psikologi Sosial. Jakarta: Salemba Humanika

\section{Jurnal}

Nursiti. 2013. Dampak Media Sosial. Jurnal NADI Media Komunikasi LPMP Jawa Barat. Jurnal psikologi. 2, (1), hlm 64-70 